\title{
Determinan kinerja guru: kompensasi dan lingkungan kerja
}

\section{(Teacher performance determinants: compensation and work environment)}

\author{
Putri Sholehati', Hady Siti Hadijah ${ }^{2^{*}}$ \\ ${ }^{1,2}$ Program Studi Pendidikan Manajemen Perkantoran, \\ Fakultas Pendidikan Ekonomi dan Bisnis, Universitas Pendidikan Indonesia \\ Jl. Dr. Setiabudhi, No. 229 Bandung, Jawa Barat Indonesia \\ Email: hady@upi.edu
}

\begin{abstract}
ABSTRAK
Penelitian dilakukan untuk mengetahui gambaran tentang kompensasi, lingkungan kerja, dan kinerja guru honorer, serta untuk mengetahui pengaruh kompensasi dan lingkungan kerja terhadap kinerja guru honorer di SMK Islamic Centre Kabupaten Cirebon. Metode penelitian yang digunakan adalah metode kuantitatif dengan metode survei. Teori yang digunakan adalah teori perilaku organisasi dari Stephen $\mathrm{P}$ Robbins. Alat pengumpulan datanya adalah angket yang diberikan kepada responden sejumlah 40 guru honorer. Teknik analisis data menggunakan analisis regresi ganda. Hasil penelitian menunjukkan bahwa (1) gambaran tentang kompensasi tinggi (2) gambaran tentang lingkungan kerja kondusif (3) gambaran tentang kinerja guru honorer sedang (4) terdapat pengaruh dari kompensasi dan lingkungan kerja terhadap kinerja guru honorer baik parsial maupun simultan.
\end{abstract}

Kata Kunci: Kompensasi, Lingkungan Kerja, Kinerja Guru

\begin{abstract}
The study was conducted to determine the description of compensation, work environment, and performance of honorary teachers, and to determine the effect of compensation and the work environment on the performance of honorary teachers at the Cirebon Islamic Center SMK. The research method used is a quantitative method with a survey method. The theory used is the theory of organizational behavior from Stephen P Robbins. The data collection tool is a questionnaire given to respondents of 40 honorary teachers. The data analysis technique uses multiple regression analysis. The results of the study show that (1) the description of high compensation (2) a description of the conducive work environment (3) an overview of the performance of moderate honorary teachers (4) there is an effect of compensation and work environment on the performance of honorary teachers both partially and simultaneously.
\end{abstract}

Keywords: Compensation; Work Environment; Teacher Performance

Received: Februari 2019, Revision: Mei 2019, Published: Juli 2019

*Corresponding author

Copyright @ 2019, EISSN 2656- 4734 


\section{PENDAHULUAN}

Pendidikan adalah proses belajar untuk menciptakan individu yang berkualitas. Melalui pendidikan, potensi yang terdapat pada individu peserta didik dapat menjadi nyata sehingga individu tersebut menjadi individu yang memiliki kemampuan yang dapat diimplementasikan bagi kepentingan sesama. Dalam jangka panjang,, pendidikan diharapkan dapat berkontribusi dalam meningkatkan pembangunan bangsa.

Guru adalah salah satu faktor utama yang mendorong proses pendidikan menjadi lebih maju dan berkualitas. Pendidikan yang berkualitas akan menghasilkan peserta didik yang berkualitas pula. Dengan demikian guru berperan penting dalam rkaitan dengan hal tersebut, Mulyasa (2008, hal. 28) menyatakan bahwa guru adalah seorang pendidik yang berperan penting dalam meningkatkan kualitas peserta didik. Mereka bertugas membimbing dan mengarahkan cara belajar peserta didik agar mencapai hasil maksimal. Guru sangat menentukan keberhasilan peserta didik terutama dalam kaitannya dengan proses belajar mengajar.

Kinerja guru sangat menentukan keberhasilan proses belajar peserta didik sehingga tujuan pendidikan dapat tercapai dan terwujud dari hasil belajar peserta didik yang baik. Agar kinerja guru yang baik tercapai maka pemerintah atau yayasan sekolah harus memperhatikan kebutuhan-kebutuhan yang diharapkan oleh guru karena pada kenyataannya di Indonesia masih banyak jumlah guru yang berstatus honorer dibanding yang sudah berstatus PNS. Berdasarkan fakta di salah satu SMK swasta bahwa kinerja guru honorer belum maksimal karena rendahnya kompensai mereka. Bersamaan dengan hal ini, Mulyasa (2008, hal. 28) menyatakan bahwa rendahnya kualitas guru akan berpengaruh terhadap daya saing dan kualitas peserta didik. Tercapainya kualitas guru terjadi apabila dapat dipenuhinya kebutuhan-kebutuhan yang diharapkan oleh guru.

Salah satu cara manajemen untuk meningkatkan prestasi kerja, memotivasi, dan meningkatkan kinerja para karyawan adalah melalui kompensasi . Jika organisasi menerapkan upah atau kompensasi yang terkait langsung dengan kinerja organisasi, maka karyawan akan merasa terpacu untuk bekerja dengan lebih baik lagi. Hal ini disebabkan adanya hubungan positif antara kinerja perusahaan sebagai akumulasi dari kinerja setiap karyawan dan kompensasi yang diterimanya (Ati Cahayani, 2010, hal. 91). Kinerja guru yang baik dapat dijelaskan oleh kompensasi yang layak, baik kompensasi langsung maupun tidak langsung, baik finansial, maupun non finansial. Hal ini bearti buruknya kineja guru honorer dapat dijelaskan akibat rendahnya kompensasi yang diterima

Selain kompensasi, salah satu faktor yang diinginkan oleh pekerja untuk meningkatkan kinerja mereka adalah lingkungan kerja. Lingkungan kerja yang baik akan meningkatkan kinerja yang lebih baik. Artinya, lingkungan kerja merupakan faktor yang mempengaruhi kinerja seseorang. seseorang (Rabia Imran., 2012, hal. 3). Seiring dengan pengertian tersebut Siagian (2009, hal. 56) menyatakan bahwa pencapaian kinerja unggul dari karyawan ditentukan oleh beberapa faktor, yaitu kompensasi, lingkungan kerja, budaya organisasi, kepemimpinan dan motivasi kerja, disiplin kerja, kepuasan kerja, komunikasi dan faktor-faktor lainnya (Siagian, 2009, hal. 56). Dari beberapa faktor yang mempengaruhi kinerja menurut Siagian, peneliti memfokuskan penelitian ini hanya pada dua faktor saja, yaitu kompensasi dan lingkungan kerja. 


\section{TINJAUAN PUSTAKA}

\section{Kompensasi}

Kompensasi adalah bentuk balas jasa atau imbalan kepada pegawai/karyawan karena pegawai/karyawan tersebut telah menyelesaikan tugasnya. Upah dan gaji merupakan bentuk kompensasi (Davis dalam Hasibuan, 2007, hal. 119). Menurut Hasibuan (2008, hal. 118), imbalan tersebut bukan hanya uang tetapi juga barang. Keduanya merupakan imbalan kepada pegawai/karyawan. Sukamti (1989, hal. 232) dan Simamora (2004, hal. 191) memiliki pengertian yang lebih luas terhadap imbalan, yakni imbalan dapat berupa finansial ataupun non finansial. Ranupandojo (2000, hal. 10) mengaitkan kompensasi terhadap karyawan tersebut dengan prestasinya. Menurut Ranupandojo, kompensasi adalah bentuk balas jasa kepada pekerja/karyawan dan agar pekerja/karyawan ersebut terdorong untuk lebih berprestasi hendaknya pihak manajemen menggunakan system kompensasi yang baik.

Banyak faktor yang dapat mempengaruhi besarnya kompensasi yang diberikan kepada karyawan. Menurut Edy Sutrisno (2009, hal. 191), faktor-faktor yang mempengaruhi kompensasi adalah tingkat biaya hidup, kompensasi yang diberikan perusahaan pesaing. Selain itu, faktor-faktor tersebut adalah kemampuan perusahaan, jenis pekerjaan, besarnya tanggung jawab, dan serikat buruh/pekerja. Hampir sama dengan pendapat Edy Sutrisno, Hasibuan memamndang dari sisi supply dan demand. Menurut Hasibuan (2007, hal. 127), besarnya kompensasi tergantung pada demand dari perusahaan yaitu kondisi perekonomian nasional, undang-undang ketenagakerjaan, dan ketersediaan formasi kosong di perusahaan; tergantung juga pada supply tenaga kerja yaitu pendidikan dan pengalaman, dan biaya hidup di kota di mana perusahaan berada. Masih menurut Hasibuan, selain faktor supply dan demand, terdapat faktor-faktor lain yang mempengaruhi besarnya kompensasi, yaitu jenis pekerjaan dan produktivitas kerja.

\section{Lingkungan Kerja}

Dalam suatu organisasi diperlukan perhatian terhadap lingkungan kerja agar pekerja dapat melaksanakan tugas tanpa mengalami gangguan sehingga pekerja dapat mencurahkan perhatiannya terhadap pekerjaan. Lingkungan kerja adalah segala sesuatu yang berada di sekitar pekerja yang dapat mempengaruhi konsentrasi kerja. Lingkungan kerja dapat mempengaruhi knsentrasi seseorang. Oleh karena itu lingkungan kerja perlu mendapat perhatian pihak manajemen karena lingkungan kerja yang buruk akan mengganggu konsentrasi seseorang dalam bekerja (Nitisemito, 2008, hal. 183). Termasuk dalam lingkungan kerja adalah metode kerja dan pengaturan kerja. Menurut Sedarmayanti, lingkungan kerja adalah segala sesuatu yaitu alat/bahan yang berada di sekitar kita mencakup metode kerja dan pengaturan kerja, baik untuk perorangan maupun kelompok. Jadi metode kerja dan pengaturan kerja perlu selalu dievaluasi oleh pihak perusahaan/manajemen untuk tetap mempertahankan konsentrasi pekerja yang tinggi. Musik, penerangan, dan kebersihan juga termasuk lingkungan kerjakarena dapat mempengaruhi pekerja dalam menjalankan tugasnya (Sunyoto, 2012, hal. 43). Menurut Susiliowati (2005, hal. 40), segala sesuatu yang berada di sekitar pekerja yang di sebut lingkungan kerja tersebut dapat berpengaruh terhadap pekerja dengan cara langsung maupun tidak langsung.

Selanjutnya Rabia Imran (2012, hal. 1456), mengatakan bahwa lingkungan kerja adalah faktor-faktor yang berkaitan dengan pekerja yang mempengaruhi hubungan 
antara karyawan dengan perusahaan atau pegawai dengan instansinya. Agak berbeda definisi lingkungan kerja menurut Sofyandi (2008, hal. 38). Sofyandi mengitkan lingkungan kerja dengan prestasi kerja. Menurut Sofyandi, faktor internal organisasi atau lingkungan kerja dapat mempengaruhi prestasi dari pekerja. Lingkungan kerjayang baik akan meningkatkan prestasi pekerja, sebaliknya lingkungan kerja yang buruk akan menurunkan prestasi kerja.

Menurut Anwar Prabu Mangkunegara (2005, hal. 105), perilaku kerja karyawan dibentuk oleh lingkungan kerja yang terdiri dari kondisi fisik dan kondisi psikologis. Kondisi fisik yaitu tata ruang, kebersihan, dan kerapihan ruang, sedangkan kondisi psikologis (non fisik) yang turut mempengaruhi perilaku kerja adalah rasa bosan terhadap pekerjaan, keletihan akibat kerja rutin tanpa istirahat, kondisi lingkungan social, status social karyawan yang bersangkutan, hubungan kerja dalam perusahaan, dan sistem informasi yang tersedia.

Pendapat Sedarmayanti (2009, hal. 21) hamper sama dengan Anwar Prabu Mangkunegara, hanya saja Sedarmayanti memandang faktor lingkungan kerja yang mempengaruhi perilaku kerja terdiri dari efek langsung dan efek tidak langsung. Kelengkapan kerja, kemudahan menggunakan peralatan kerja, keadaan tempat kerja adalah faktor fisik yang dapat memiliki efek langsung maupun tidak langsung terhadap perilaku kerja. Demikian juga faktor non fisik seperti keadaan yang terjadi, hubungan dengan atasan, hubungan dengan rekan kerja, dan hubungan dengan bawahan dapat mempunyai efek langsung maupun tidak langsung.

\section{Kinerja Guru}

Sasaran akhir organisasi merupakan tujuan organisasi. Bagi sekolah, sasaran akhir tersebut salah satunya adalah kinerja pendidi (kinerja guru). Menurut Hamzah B. Uno (2014, hal. 70), kinerja guru adalah hasil kerja yang sudah dilakukan oleh pendidi/guru. Tugas yang sudah dilakukan tersebut terkait dengan tugas yang diterima pendidik/guru yang tiada lain merupakan tanggung jawab seorang pendidi/guru. Menurut A. Tabrani Rusyan (2000, hal. 17), tugas guru bukan hanya di dalam kelas. Tugas-tugas di luar kelas juga masih menjadi tanggung jawab guru. Tugas-tugas guru tersebut selain mengajar adalah tugas administrasi sekolah, administrasi proses kegiatan belajar, bimbingan terhadap siswa, memberikan penilaian terhadap siswa.

Guru di sekolah harus dapat meningkatkan kinerjanya karena kinerja guru merupakan ukuran dari tingkat kinerja yang dicapai oleh sekolah. Kinerja guru adalah ukuran dari tingkat cakupan efektifitas dari isi yang diharapkan oleh kurikulum dari guru. Dengan demikan fungsi dari bagaimana isi dari pekerjaan sekolah secara efektif dapat dicapai. Hamzah B. Uno (2014, hal. 71) menjelaskan bahwa baik tidaknya kinerja guru dapat dilihat dari kualitas kerja, inisiatif kerja, kemampuan kemampuan kerja, dan tak kalah pentingnya adalah cara komunikasi yang dilakukan. Faktor-faktor yang dapat mempengaruhi kinerja guru adalah kompensasi (Ranupradojo, 2000, hal. 10) dan lingkungan kerja (Sofyandi, 2008, hal. 38)

Berdasarkan tinjauan pustaka di atas, dapat digambarkan theoretical framework sebagai berikut: 


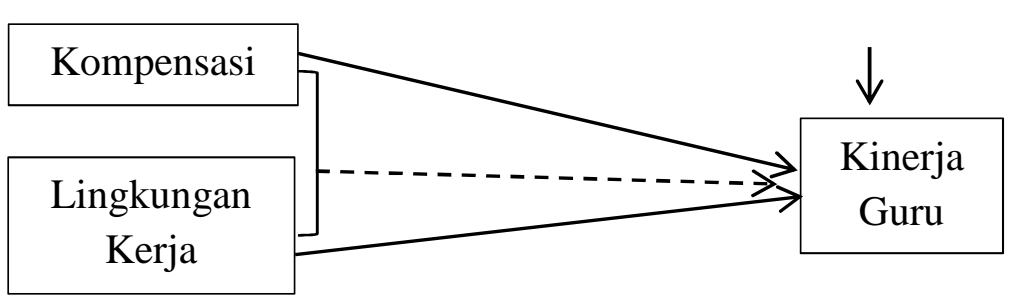

\section{Gambar 1 Theoretical Framework}

\section{METODOLOGI}

Penelitian dilakukan untuk menjawab tujuan dari penelitian, yaitu untuk melihat gambaran tentang kompensasi, lingkungan kerja, dan kinerja guru honorer serta untuk mengetahui ada tidaknya pengaruh pengaruh dari kompensasi dan lingkungan kerja terhadap kinerja guru honorer. Metode penelitian kuantitatif dan survey digunakan dalam penelitian ini. Unit yang dianalisis dalam penelitian ini adalah 40 guru honorer. Instrumen pengumpulan data menggunakan angket dengan skala likert. Teknik analisis statistik yang digunakan dalam mengolah data adalah teknik analisis deskriptif dan teknik analisis inferensial. Statistik deskriptif digunakan untuk mengetahui gambaran tentang kompensasi, lingkungan kerja, dan kinerja yang digambarkan dalam tabel distribusi frekuensi dan persentase. Statistik inferensial digunakan untuk melihat pengaruh dari kompensasi dan lingkungan kerja terhadap kinerja guru honorer melalui analisis regresi ganda dengan software Microsoft Office Excel 2010. Uji hipotesis menggunakan uji t dan uji F.

\section{HASIL PENELITIAN DAN PEMBAHASAN}

Data yang diperoleh dari lapangan kemudian diolah setelah skala diubah terlebih dahulu melalui program Methods Succesive Interval (MSI). Hasil analisis deskripsi masing-masing variabel diperoleh sebagai berikut:

\section{Kompensasi}

Berdasarkan perhitungan dari 40 responden, berikut adalah gambaran mengenai kompensasi dapat dilihat pada Tabel 1 di bawah ini :

\section{Tabel 1.}

Kompensasi

\begin{tabular}{|l|c|c|c|}
\hline \multicolumn{5}{c}{ Kompensasi } \\
\hline Indikator & Item & Rata-rata & Penafsiran \\
\hline Gaji/Upah & $1-2$ & 3,525 & Tinggi \\
\hline Insentif & $3-4$ & 3,188 & Sedang \\
\hline Tunjangan & $5-6$ & 3,888 & Tinggi \\
\hline Fasilitas & $7-8$ & 3,66 & Tinggi \\
\hline \multicolumn{2}{|c|}{ Rata-rata } & $\mathbf{3 , 5 6 6}$ & Tinggi \\
\hline
\end{tabular}

Tabel 1. menunjukkan bahwa rata-rata skor jawaban responden untuk variabel kompensasi guru honorer sebesar 3,566. Apabila dihubungkan dengan skala penafsiran pada tabel rekapitulasi skor kriterium, maka angka tersebut berada pada rentang 3,40 - 
4,19 atau berada pada kategori tinggi. Indikator tertinggi yaitu tunjangan, serta indikator terendah yaitu insentif.

\section{Lingkungan Kerja}

Berdasarkan perhitungan dari 40 responden, gambaran mengenai lingkungan kerja dapat dilihat dari Tabel 2 yang menunjukkan bahwa rata-rata skor jawaban responden untuk variabel lingkungan kerja sebesar 3,807. Jika dikaitkan dengan skala penafsiran pada tabel rekapitulasi skor kriterium, maka angka tersebut berada pada rentang 3,40 - 4,19 atau berada pada kategori tinggi. Indikator tertinggi yaitu hubungan kerja dengan atasan, bawahan, maupun sesama rekan kerja, serta indikator terendah yaitu kebisingan.

Tabel 2.

Lingkungan Kerja

\begin{tabular}{|l|c|c|c|}
\hline \multicolumn{4}{|c|}{ Lingkungan Kerja } \\
\hline \multicolumn{1}{|c|}{ Indikator } & $\begin{array}{c}\text { Ite } \\
\text { m }\end{array}$ & $\begin{array}{c}\text { Rata- } \\
\text { rata }\end{array}$ & Penafsiran \\
\hline Kelengkapan Peralatan Kerja & 1 & 3,75 & Tinggi/Kondusif \\
\hline Kemudahan Penggunaan Peralatan Kerja & 2 & 4,025 & Tinggi/Kondusif \\
\hline Kebersihan Lingkungan Kerja & 3 & 3,925 & Tinggi/Kondusif \\
\hline Luasnya Ruangan & 4 & 3,975 & Tinggi/Kondusif \\
\hline Penerangan/Pencahayaan & 5 & 3,675 & Tinggi/Kondusif \\
\hline Kebisingan & 6 & 3,325 & $\begin{array}{c}\text { Sedang/Cukup } \\
\text { Kondusif }\end{array}$ \\
\hline Pewarnaan Dinding & 7 & 3,825 & Tinggi/Kondusif \\
\hline Sirkulasi Udara & 8 & 3,950 & Tinggi/Kondusif \\
\hline Kenyamanan Tata Ruang & 9 & 3,575 & Tinggi/Kondusif \\
\hline $\begin{array}{l}\text { Hubungan Kerja dengan Atasan, Bawahan, maupun } \\
\text { sesama Rekan Kerja }\end{array}$ & $10-$ & 4,063 & Tinggi/Kondusif \\
\hline \multicolumn{1}{|c|}{ Rata-rata } & 13 & $\mathbf{3 , 8 0 7}$ & Tinggi/Kondusif \\
\hline
\end{tabular}

\section{Kinerja Guru}

Berikutnya adalah Tabel 3. menunjukkan gambaran tentang kinerja guru yang diperoleh dari perhitungan terhadap 40 responden.

Tabel 3

Kinerja Guru

\begin{tabular}{|l|c|c|c|}
\hline \multicolumn{4}{|c|}{ Kinerja Guru } \\
\hline \multicolumn{1}{|c|}{ Indikator } & Item & Rata-rata & Penafsiran \\
\hline Kualitas Kerja & $1-3$ & 3,48 & Tinggi \\
\hline Kecepatan/Ketepatan Kerja & $4-7$ & 3,35 & Sedang \\
\hline Inisiatif Dalam Bekerja & $8-9$ & 3,25 & Sedang \\
\hline Kemampuan Kerja & $10-12$ & 3,61 & Tinggi \\
\hline Komunikasi & 13 & 3,27 & Sedang \\
\hline \multicolumn{1}{|c|}{ Rata-rata } & $\mathbf{3 , 3 9}$ & Sedang \\
\hline
\end{tabular}


Tabel 3 menunjukkan bahwa rata-rata skor jawaban responden untuk variabel kinerja guru honorer sebesar 3,39. Jika dihubungkan dengan skala penafsiran pada tabel rekapitulasi skor kriterium, maka angka rata-rata pada variabel kinerja guru berada pada rentang 2,60 - 3,39 yaitu masuk kategori sedang. Indikator tertinggi yaitu kemampuan kerja, serta indikator terendah inisiatif dalam bekerja.

\section{Pengaruh Kompensasi Terhadap Kinerja Guru Honorer}

Untuk mengetahui ada tidaknya pengaruh dari variabel kompensasi terhadap kinerja guru honorer dilakukan pengujian dengan uji $t$ dan didapatkan nilai $t_{\text {hitung }}$ sebesar 4,5908 dan nilai $t_{\text {tabel }(0,05 ; 40-2-1)}$ sebesar 2,0262. Dengan demikian, nilai $t_{\text {hitung }}>$ nilai $t_{\text {tabel }}$ $(4,5908>2.0262)$, sehingga $\mathrm{H}_{0}$ ditolak dan $\mathrm{H}_{1}$ yang menyatakan terdapat pengaruh kompensasi terhadap kinerja guru honorer diterima, artinya bahwa kompensasi berpengaruh terhadap kinerja guru honorer.

Nilai koefisien korelasi antara variabel kompensasi dengan kinerja guru honorer adalah 0,4754. Jika dihubungkan dengan kriteria interpretasi koefisien korelasi, angka tersebut berada pada rentang 0,400 - 0,599 yaitu masuk kategori sedang/cukup kuat. Adapun nilai koefisien determinasi kompensasi terhadap kinerja guru adalah $23 \%$.

\section{Pengaruh Lingkungan Kerja Terhadap Kinerja Guru Honorer}

Untuk mengetahui ada tidaknya pengaruh variabel lingkungan kerja terhadap kinerja guru honorer dilakukan pengujian dengan menggunakan uji t dan didapatkan nilai $t_{\text {hitung }}$ sebesar 4,0686 dan nilai $t_{\text {tabel(0,05;40-2-1) }}$ sebesar 2,0262. Dengan demikian, nilai $t_{\text {hitung }}>$ nilai $t_{\text {tabel }}(4,0686>2,0262)$, maka $\mathrm{H}_{0}$ ditolak dan $\mathrm{H}_{1}$ yang menyatakan terdapat pengaruh lingkungan kerja terhadap kinerja guru dapat diterima, artinya

\section{Lingkungan kerja berpengaruh terhadap kinerja guru honorer.}

Nilai koefisien korelasi antara variabel lingkungan kerja dengan kinerja guru honorer adalah 0,3907. Jika dihubungkan dengan kriteria interprestasi koefisien korelasi , angk tersebut berada pada rentang 0,200 - 0,399 masuk pada kategori lemah. Adapun nilai koefisien determinasi lingkungan kerja terhadap kinerja guru adalah $15 \%$.

\section{Pengaruh Kompensasi dan Lingkungan Kerja terhadap Kinerja Guru Honorer}

Dalam pembahasan ini, pengaruh secara simultan dari kompensasi dan lingkungan kerja terhadap kinerja guru didasarkan pada hasil perhitungan analisis regresi ganda. Hasil perhitungan menunjukkan persamaan regresi ganda kompensasi dan lingkungan kerja terhadap kinerja guru yaitu : $\hat{Y}=-92739181,24+1265487,85 X_{1}+$ $1836858,09 \mathrm{X}_{2}$. Persamaan regresi tersebut bermakna bahwa jika tingkat kompensasi dan konusifitas lingkungan kerja meningkat, maka tingkat kinerja guru pun otomatis akan turut meningkat.

Selanjutnya, untuk mengetahui tingkat signifikansi dari pengaruh kompensasi dan lingkungan kerja terhadap kinerja guru dilakukan pengujian dengan menggunakan uji $\mathrm{F}$ dan diperoleh $\mathrm{F}_{\text {hitung }}$ sebesar 40,000 dan nilai $\mathrm{F}_{\text {tabel(0,05;2;40-2-1) }}$ sebesar 3,2519 pada taraf signifikansi 5\% dan jumlah responden adalah 40 orang. Dengan demikian, nilai $\mathrm{F}_{\text {hitung }}>$ nilai $\mathrm{F}_{\text {tabel }}(40,000>3,2519)$, maka $\mathrm{H}_{0}$ ditolak dan $\mathrm{H}_{1}$ yang menyatakan terdapat pengaruh secara simultan dari kompensasi dan lingkungan kerja terhadap kinerja guru honorer dapat diterima, artinya kompensasi dan lingkungan kerja berpengaruh secara bersama-sama terhadap kinerja guru honorer.

Nilai koefisien korelasi antara kompensasi dan lingkungan kerja terhadap kinerja guru adalah sebesar 0,5518. Jika dikaitkan dengan nilai interpretasi koefisien korelasi, 
angka tersebut berada pada rentang nilai 0,400 - 0,599 yaitu masuk kategori sedang/cukup kuat, artinya terdapat hubungan yang sedang/cukup kuat antara kompensasi dan lingkungan kerja terhadap kinerja guru honorer. Adapun nilai koefisien determinasinya adalah 30\%, artinya secara simultan variabel kompensasi dan lingkungan kerja memberikan pengaruh sebesar 30\% terhadap kinerja guru. Sisanya sebesar $70 \%$ dipengaruhi oleh faktor lain yang tidak diteliti oleh peneliti.

\section{KESIMPULAN}

Berdasarkan paparan hasil penelitian di atas, maka dapat disimpulkan bahwa kompensasi berada pada kategori tinggi dengan indikator yang paling rendah yaitu insentif, hal ini harus menjadi perhatian khusus bagi pihak sekolah. Sekolah diharapkan dapat lebih memperhatikan mengenai jumlah kompensasi yang diterima oleh guru honorer dengan cara sekolah menaikkan jumlah nominal insentif guru. Jika pihak sekolah masih belum mampu untuk menaikkan jumlah nominal insentif, maka alternatif yang lain yaitu memberikan insentif non material yang tidak berbentuk materi. Contohnya yaitu penghargaan tertulis atau pujian yang diberikan untuk guru honorer. Lingkungan kerja berada pada kategori kondusif dengan indikator yang paling rendah yaitu kebisingan. Hal ini harus menjadi perhatian khusus bagi pihak sekolah. Keadaan tempat kerja yang nyaman akan membuat guru-guru semangat dalam melaksanakan kewajiban tugasnya. Hal tersebut dapat dilakukan dengan cara membuat lingkungan sekolah yang tenang dalam artian tidak ada suara bising yang menganggu aktivitas guru. Kinerja guru honorer berada pada kategori sedang dengan indikator yang paling rendah yaitu inisiatif dalam bekerja. Hal ini menjadi perhatian khusus bagi pihak sekolah untuk menumbuhkan sifat inisiatif para guru. Sifat inisiatif dapat ditumbuhkan melalui pendidikan dan pelatihan berkala yang berkaitan dengan kemampuan teknis dan akademis dalam mengajar (hardskill) maupun pengembangan keterampilan sikap dan karakter guru (softskill) agar tercipta inisiatif dan ide-ide baru dalam proses pembelajaran. Guru juga harus bisa jadi living example yang artinya jadi contoh hidup untuk siswa. Jadi, ketika guru memiliki sifat inisiatif yang dapat memotivasi siswa dengan sendirinya akan menjadi contoh yang baik untuk siswa tersebut. Penelitian ini menunjukkan bahwa ada pengaruh kompensasi dan lingkungan kerja terhadap kinerja guru honorer baik secara parsial maupun simultan. Hubungan antar variabel berjalan searah, artinya setiap peningkatan atau penurunan pada satu variabel bebas, akan diikuti oleh peningkatan atau penurunan di satu variabel terikatnya. Dengan demikian apabila semakin tinggi tingkat kompensasi dan kondusifitas lingkungan kerja, maka akan semakin tinggi pula tingkat kinerja guru honorer, begitu pula sebaliknya.

\section{DAFTAR PUSTAKA}

A Tabrani Rusyan., C. W. (2000). Kemampuan Dasar Guru Dalam Proses Belajar Mengajar. Bandung: Remaja Rosda Karya.

Anwar Prabu Mangkunegara. (2005). Sumber Daya Manusia Perusahaan. Bandung: Remaja Rosdakarya.

Ati Cahayani. (2010). Strategi dan Kebijakan Manajemen Sumber Daya Manusia. Jakarta: PT Indeks. 
Edy Sutrisno. (2009). Manajemen Sumber Daya Manusia. Jakarta: Kencana Prenada Media Group.

Hamzah B Uno., N. L. (2014). Teori Kinerja dan Pengukurannya. Jakarta: Bumi Aksara.

Hasibuan, M. S. (2007). Manajemen Sumber Daya Manusia. Jakarta: PT Bumi Aksara.

Hasibuan, M. S. (2008). Manajamen Sumber Daya Manusia. Jakarta: PT Bumi Aksara.

Mulyasa, E. (2008). Menjadi Guru Profesional Menciptakan Pembelajaran Kreatif dan Menyenangkan. Bandung: PT Remaja Rosdakarya.

Nitisemito. (2008). Pengeloaan Tentang Kondisi Kerja. Jakarta: Erlangga.

Rabia Imran., A. F. (2012). How to Boost Employee performance: Investigating The Influence of Transformational Leadership and Work Environment in a Paskitani Perspective. Middele-East Journal of Scientific Research., 1445-1462.

Ranupandojo, S. H. (2000). Manajemen Personalia. Yogyakarta: BPFE UGM.

Sedarmayanti. (2009). Tata Kerja dan Produktivitas Kerja: Suatu Tinjauan Dari Aspek Ergonomi Atau Kaitan Antara Manusia Dengan Lingkungan Kerjanya. Bandung: Mandar Maju.

Siagian, S. P. (2009). Kiat Meningkatkan Produktivitas kerja. Jakarta: PT Rineka Cipta.

Simamora, H. (2004). Manajemen Sumber Daya Manusia. Yogyakarta: STIE YKPN.

Sofyandi, H. (2008). Manajemen Sumber Daya Manusia. Yogyakarta: Penerbit Graha Ilmu.

Sukamti. (1989). Manajemen Personalia Sumber Daya Manusia. Jakarta: P2LPTK.

Sunyoto, D. (2012). Dasar - Dasar Manajemen Pemasaran. Yogyakarta: CAPS.

Susilowati, B. d. (2005). Dampak Kepemimpinan dan Lingkungan Kerja Terhadap Semangat Kerja. Jurnal JRBI, 1, 31 - 47. 